\title{
PUTTING OVER EUGENICS
}

\section{Making It a Living Force Depends on Sound Application of Psychology and Sociology-Camp Fire Girls an Organization Which Will Create Eugenic Ideals in Women in an Indirect but Effective Way}

\author{
A. E. Hamilton.
}

Extension Department, Eugenics Record Office, Spring Harbor, Long Island, N. Y.

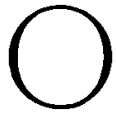

NE of the finest women, physically, mentally, spiritually, that I have been honored to meet in my lecture travels told me that she and her sisters had refrained from marriage because her family tree showed branches withered by tuberculosis.

One of the brainest and brawniest young men I have ever known told me recently that the process of trying to rationalize his emotions and bring them into line with his intellectual content regarding fitness for marriage had led him to leave the side of the woman who would have made a splendid wife had they married, and betake himself to the solitary ways of scientific research.

One of the most sympathetic and child-loving men who has crossed my path writes of breaking an engagement on the score of finding doubtfully dysgenic influences in the family of his sweetheart, of falling in love with another admirable young woman and then tearing himself out again because of something he deemed not quite fitting in her hereditary constitution, and of finding another girl who seemed quite eugenically built, but who turned him down gently but flatly when he suggested that they be married for the sake of wellbornness in children.

And I might go on recording more of this sicklying o'er with the pale cast of bluegenic thought the young minds of potential parents, which seems to me almost the net result of many of the wellintended but myopic endeavors hitherto made to put over Galton's idea to the coming generation. Perhaps it is time for those of us who have the welfare of Eugenics at heart to ask ourselves what there is in a monograph on albinism, a study of the inheritance of idiocy, or a lecture on the declining birth-rate in college women or American men of science, to promote a desire on the part of our fittest young people for marriage and parenthood-for if that be not the keynote of Eugenics, then I sadly misconstrue the meaning of the word.

To which it may be answered that all our normal young folks desire marriage and parenthood-whereupon the question becomes; Do they desire it enough to overcome the obstacles, psychological, social and economic, that are thrust in their way because the conscious attention of those who should be educators and leaders has not been turned on these problems sufficiently to make a dent in them? Marriage and parenthood must ever remain matters of desire, and the work before the true promoter of Eugenics is that of social engineering which will make for the realization of desire in the wholesomest and quickest way. The man whose genius has given us the first self-supporting social institution designed for the most genuine racebetterment puts the challenge thus, "Can you develop the geniuses who will parallel in the social world what our inventors have done in the world of steam and electricity? Can you then create social self-supporting institutions that shall take these social inventions and so put the power of organization, publicity and finance behind them that they shall be as wide spread as the telephone, the movies or the telegraph?" In the organization of the Camp Fire Girls, the brain child of Doctor and Mrs. Luther Halsey Gulick, we have the pioneer type of such self-reliant and self-supporting institutions as will doubtless spring up 


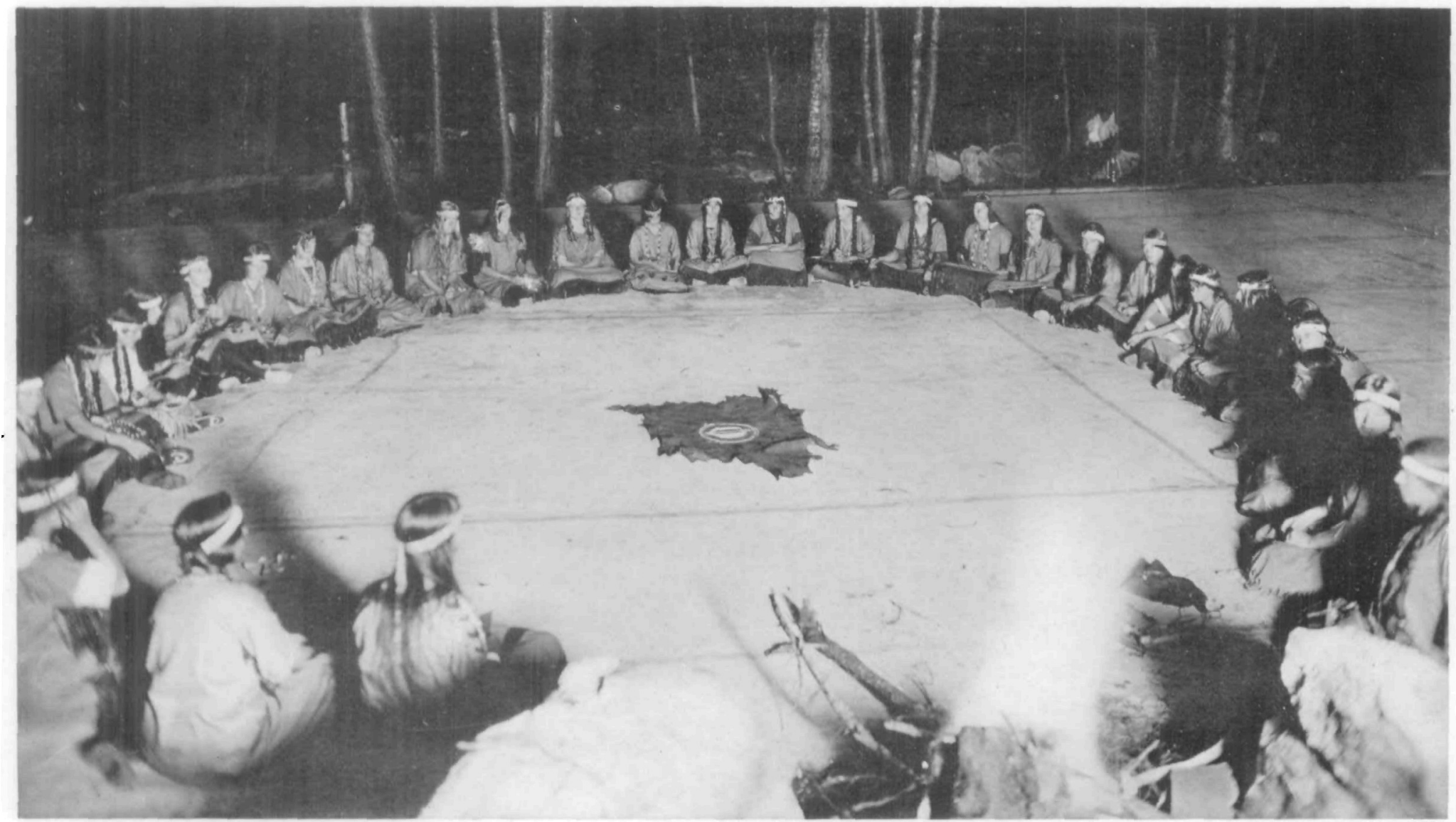

THE CAMP-FIRE CIRCLE

As far as is possible, Camp Fire girls are trained to act as hostesses in their communities. On such occasions as the one here pictured, they learn to seek the best side of the character of each individual, and to show that side to the individual and to others. What this may mean to the Eugenics movement is pointed out by Mr. Hamilton in the text. Photograph by Mrs. Luther H. Gulick. (Fig. 10.) 


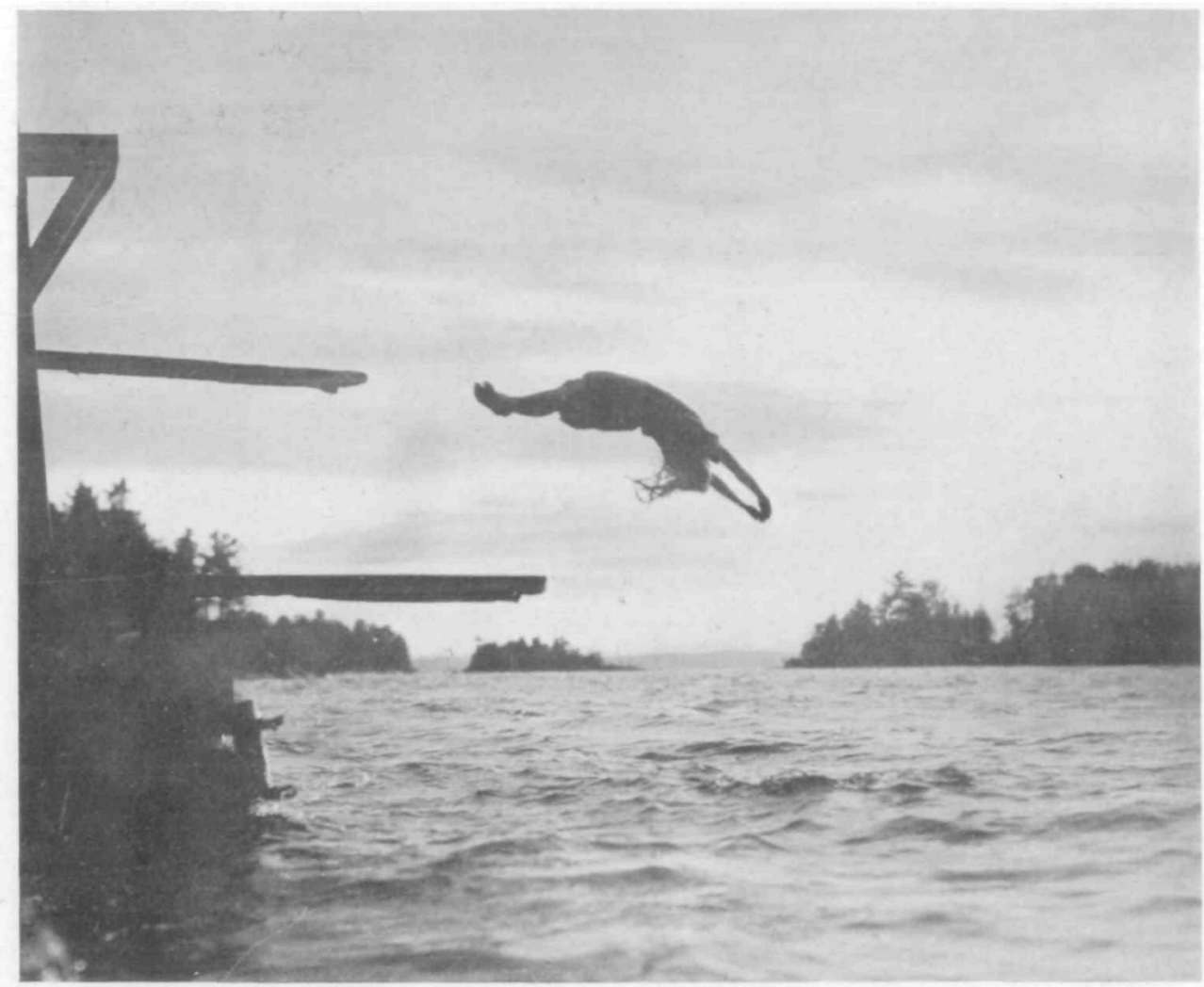

DEVELOPING THE BODY

Water sports and other carefully chosen forms of recreation are, in connection with the other Camp Fire activities, developing a spirit of physical and mental freedom in girls that will affect for good the parenthood of the next generation. Photograph by Mrs. Luther $\mathrm{H}$. Gulick. (Fig. 11.)

to meet the demands of our new day. That here we have a splendid instrument for the promotion of true Eugenic ideals is sure if the words of its founder are made good, and from my own firsthand observations I should say that already they are being splendidly realized:

\section{IDEAL OF THE FOUNDERS.}

"Camp Fire Girls undertake in so far as they are able to act as Hostesses for their communities. The word Hostess brings to mind not so much one who is correct in matters of social usage as a woman who understands, who has insight, sympathy and tact. She often enables people to do what they never knew they had it in them to do. She reveals people even more to themselves than she helps them reveal themselves to others. She draws out each one's abilities by her power of intelligent appreciation. To her the arts of entertaining are those which bring people together, which reveal people to each other, which develop the social nature. To amuse is not her object, but to so treat her guests that the best in each is developed and fed by the best in everyone else. This is social genius. Camp Fire Girls aim to discover, develop and use social genius just as previous generations have discovered and used scientific genius. Into this work is being thrown an army of picked girls under the guidance of the ablest women. As they grow in power of team work, preserving the devotion and vision of youth, gaining 


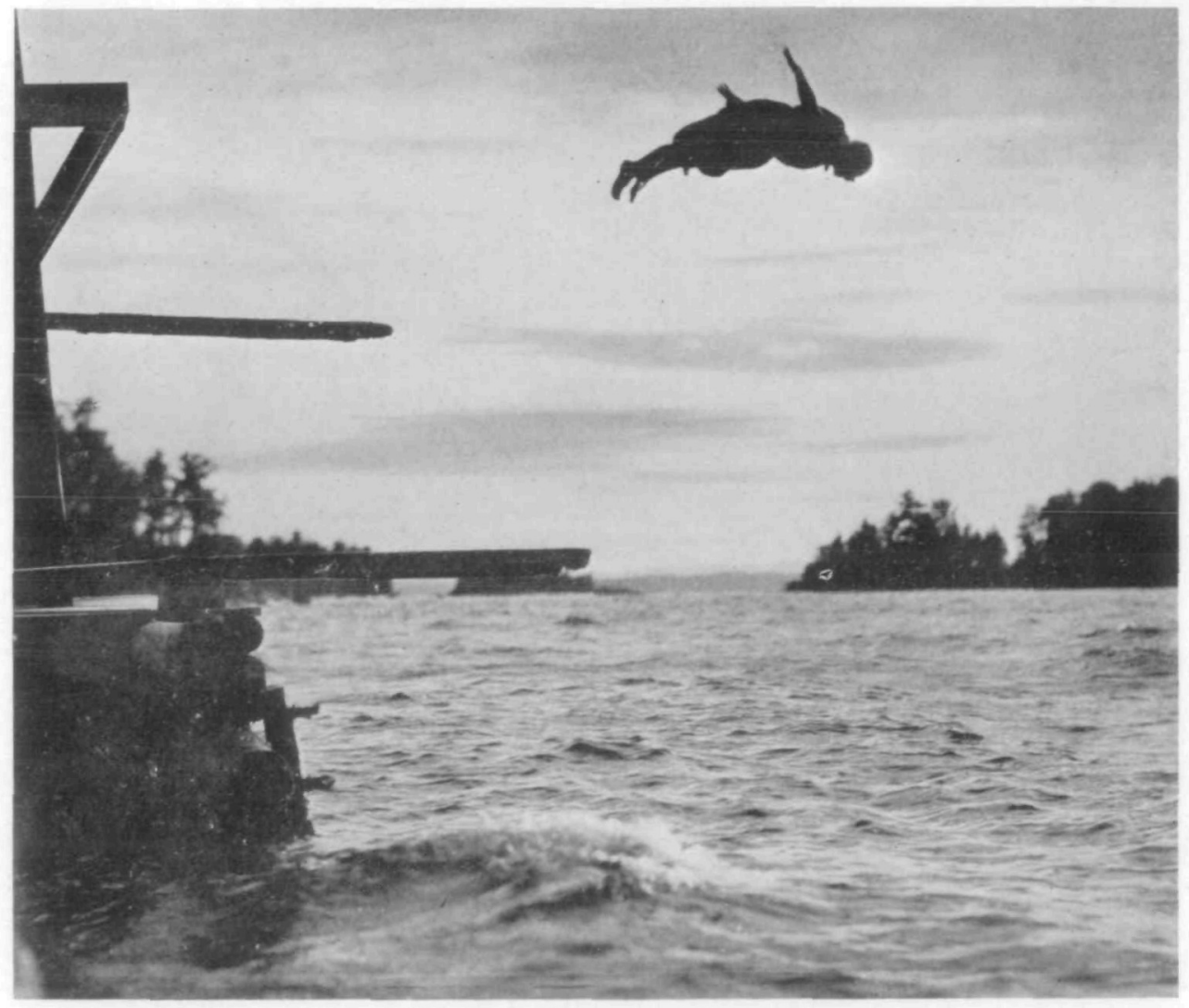

\section{GIRLS MUST BE PHYSICALLY FIT}

The Camp Fire is intended to educate girls in the true sense - that is, to give as full opportunity as possible to their valuable inborn characteristics to get expression. Physical fitness is one that, in the interests of the race, is naturally insisted upon. Photograph by Mrs. Luther H. Gulick. (Fig. 12.)

vision by experience, who shall say that they will not do for the affections as brilliantly as the previous generation has done for the industries. Both of these had their origin in the home but have grown beyond its confines."

"Camp Fire Girls is an organization of girls and women to develop the home spirit and make it dominate the entire community. Hence, the ranks should be recruited from those who have ability to do and to help rather than from those who need help. It is an army of girls rather than a mission to them. Military training is good for the health, but an army cannot be built out of invalids, selected because they need the outdoor life and exercise of a soldier. The purpose of Camp Fire is to find the ablest girls and women and to give them a training in team work that will enable and incline them effectively to give woman's service to the community. Girls and guardians do become improved by Camp Fire work just as the soldier is benefited by the army drill, but self improvement is no more the object for the girls than it is for the soldier. The primary purpose is to develop ideals, to train leaders, to create custom and fashion, habit and want. As Camp Fire girls grow up into women, they will have the training, experience and affection to help organize and carry on all of the social relations of the community, including the care of those who primarily need help. There are many institutions 


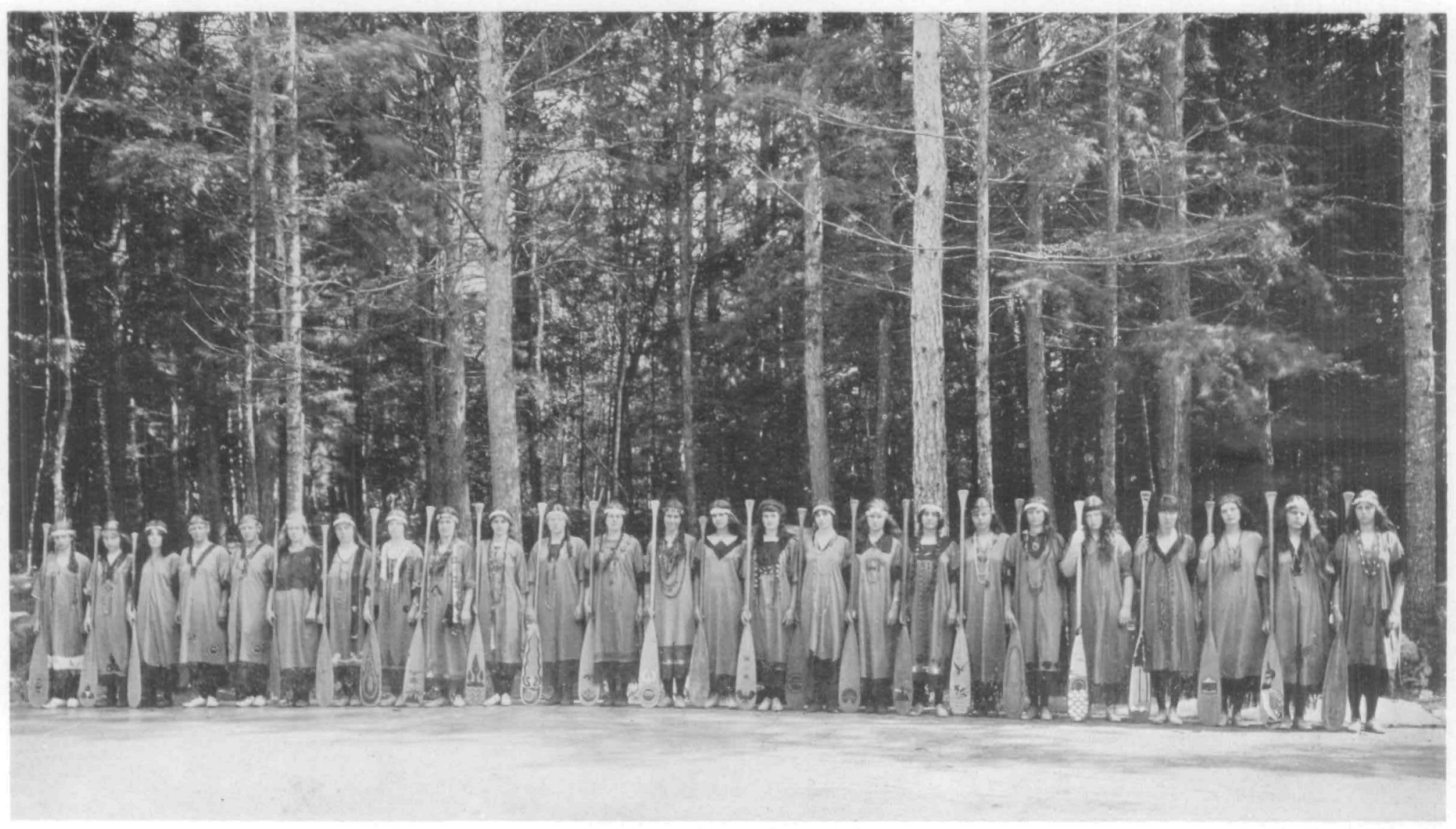

"CAMP FIRE IS AN ARMY, NOT A HOSPITAL."

The organization is not intended primarily as a training school for the unfortunate, but as a training school for those who by birth and in other respects are likely to be leaders. It aims to help the mass of the population indirectly rather than directly, by turning out women who will be able and willing to disseminate its ideals in their own communities. Photograph by Mrs. Luther H. Gulick. (Fig. 13.) 


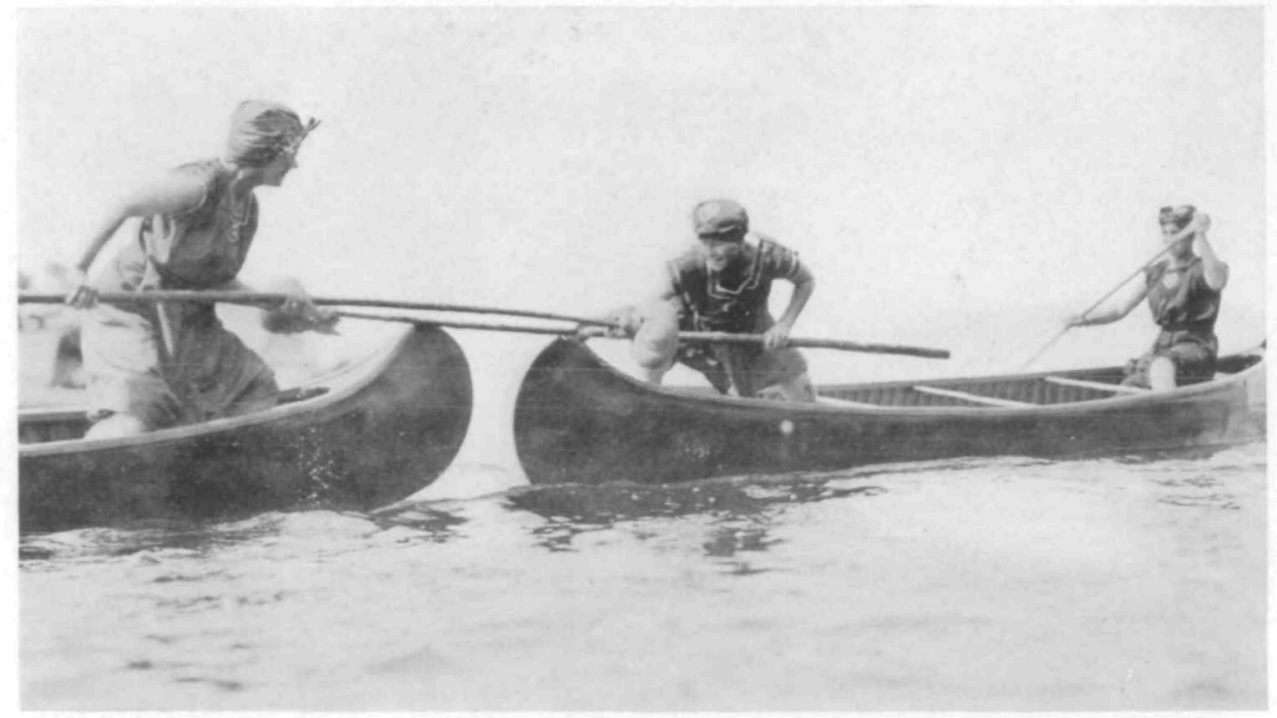

GAINING CONTROL OF SELF

Fitness for motherhood is a happy by-product of Camp Fire activities, which make for splendid physique and intelligent control of one's own body and mind, and of Nature as we find her. Photograph by Mrs. Luther H. Gulick. (Fig. 14.)

of the hospital type, devoted to the unfortunate, and a few-if any-are working on this task to which we have devoted ourselves-that of building up an army of splendid women, trained in team work, devoted to the spiritual ideals of the home, and united in giving service to the community."

On being asked how Camp Fire girls were instructed and trained for motherhood, the mother out of whose homecamp life the movement originally sprang replied that no particular training or instruction was given to girls that could be labelled "for motherhood." The concept motherhood will not shrink into a course of training or into a text book. It is to be lived, not defined or imparted. Camp Fire girls win honor beads by work in scven crafts-health craft, camp craft, nature lore, home craft, hand craft, business and patriotism. As each girl receives honors she progresses from rank to rank in her group and in the organization, so that each attainment of an honor represents the realization of a desire for definite accomplishment. If the home craft honors lure girls to do those things that inevitably make for the best in home building and tending, if health craft and camp craft and Nature lore bring strong bodies, tested nerves and a realization of the mystery and purpose of love in the world of living things, then a big part of training for motherhood is accomplished as a by-product. But the girls have not been striving to become good mothers according to rule. They have been "seeking beauty," (which is the first of the seven laws of the Camp Fire) in a multitude of wisely selected and elective activities, and all the rest will have been addsd unto them.

\section{EMBODIMENT OF EUGENICS}

So, too, Eugenics, though nowhere mentioned in the literature of Camp Fire, finds its embodiment in the learning by doing which is Camp Fire. "To know the names, homes and occupations of grand-parents" for the earning of an honor in Patriotism, takes a girl into the fascinating ficld of genealogy where a little observation will suggest the segregation of hereditary characters, physical and mental, in the family history and so open up the study 


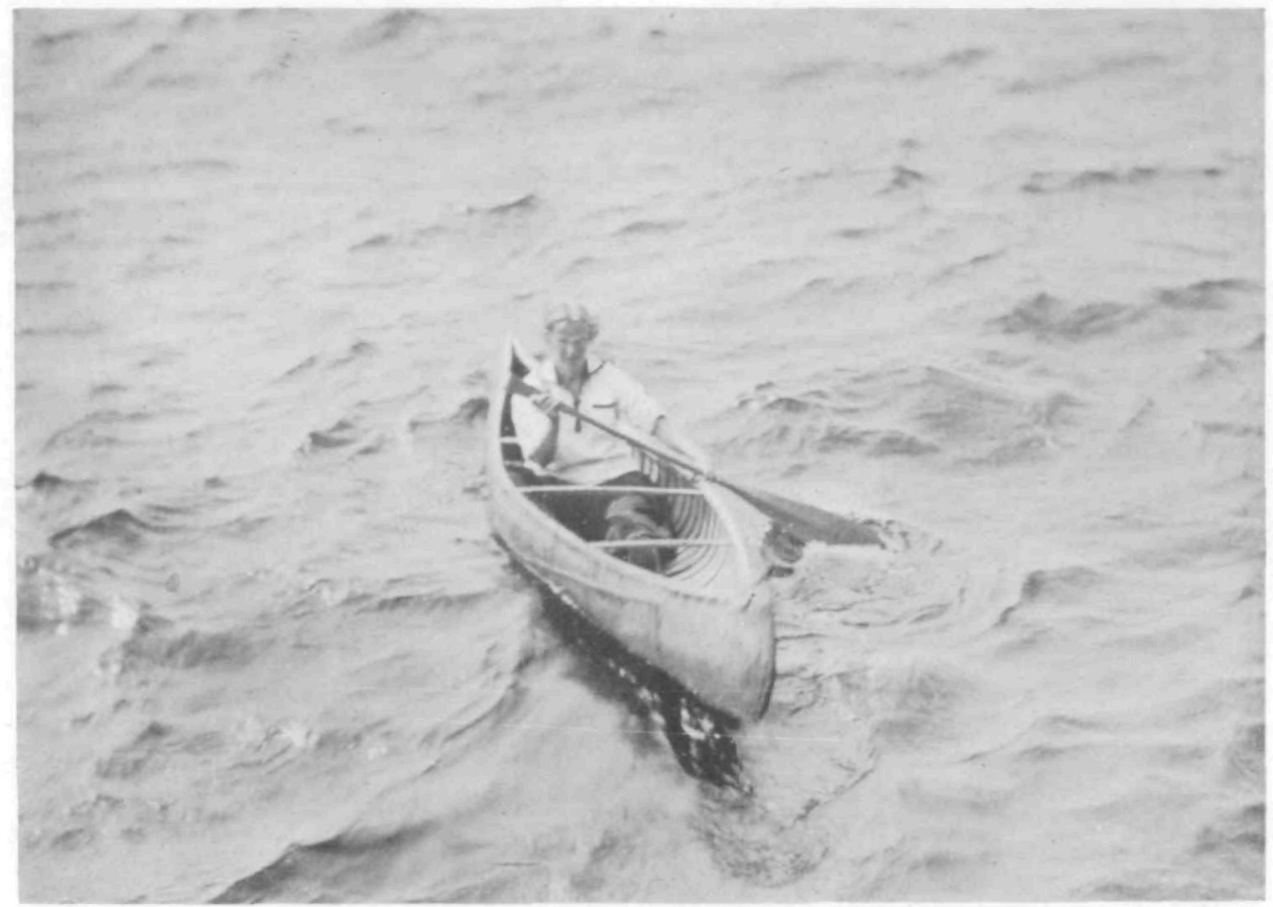

A TEST OF SELF-RELIANCE

Only those who have tried paddling a birch-bark canoe in rough water and wind can appreciate the kinds of qualities that this girl is developing. Photograph by Mrs. Luther $\mathrm{H}$. Gulick (Fig. 15.)

of inheritance in a natural, positive and interesting way.

To "investigate the effects of ventilation and sanitation in stores and factories employing women," another elective requirement for a bead, might lead to inquiries concerning the transmission of acquired characters, the difference between immediate effects of environment on women and their children and the strictly racial modifications of circumstance and time. The "study of ten public institutions in her locality" can hardly fail to acquaint a girl with the purpose and content of the poor-house, jail, insane asylum or home for the feeble in mind, and such a study, amateur and superficial as it may be, will bite deeper into the mind than the reading of a shelf full of official reports later on. A patriotism paper on Immigration brings up the great issues of value in human stock and the right to enter our gates. Studied and written about in a spirit of interest in subject matter plus the desire for accomplishment and the relation of the part to the whole, the Jukes and Ishmaelites and gunmen who flood into our country through the leaks in our immigration laws become real and living, and who that knows the slightest of the psychology of adolescence will doubt that such an interest, so stimulated, will influence the vote to be cast on these questions a few years later?

"To be familiar with National History as it affects woman's welfare" has already led two Camp Fire girls of my own acquaintance, walking in entirely different spheres, to hit upon the idea of camp fire and scouting activities as small beginnings of what William James dreamed might prove a moral equivalent of war.

Thus "the study of agencies under social control that may improve or impair the racial qualities of future generations either physically or mentally" is begun quite unconsciously, and 
carried far beyond the academic stage of reading, writing and discussion, into the play-practice by a coming generation that will better fit it for facing these big world problems than perhaps any generation has ever been fitted before.

From fifty to seventy thousand young girls absorbing the Camp Fire environment, and their numbers increasing at the rate of about 2,000 girls a month, actually means something for the future of the race. The hiking, canoeing, swimming, cooking, and all-round glorification of work which seemed to my young friends a possible "moral equivalent of war," is developing a spirit of physical and mental freedom that will doubtless result in a finer fitness for motherhood and a keener perception of what is wanted in fatherhood for the next generation. It will also be found to be working out a solution for many an economic problem that results from our extravagance in luxuries, which are more than compensated for in the happy recreations of the out-of-doors and the simplifying of customs of eating and all-round living that comes with an appreciation of a life close to the heart of nature, whose wayward children we still are, despite our carapace of over-civilization.

\section{THE TORCH-BEARERS}

The highest rank in Camp Fire is that of the torch-bearer, whose desire, expressed on receiving the honor, is:

"The light that has been given to me

I desire to pass undimmed to others."

And its biological and social significance is made plain to those who work for and win the rank. In such a spirit we may hope to find at least the beginning of a realization of Galton's hope that Eugenics might beccme a living part of our very religious conception of life; for surely, as Saleeby has aptly put it: "If we have trans- ferred our hopes of heaven to earth, and from ourselves to our children, they are no less religious, 'and they that shall be of us shall build up the old waste places; for we shall raise up the foundations of many generations.' "

Nor need this be conscious or reasoned. Perhaps the less we say to our young people about Eugenics directly, the better. Surely the less they have to deal first-hand with the blacksymboled pedigrees of neuroses and disease that constitutes the major part of our present crop of eugenic literature, the more wholesome will be their attitude toward their own relation to life and its multiplication. It. is not so much seeds of fear concerning going wrong that we need to sow, as it is seeds of strong desire to go right and pass on undimmed the light that is given us in a spirit of hope that the best is yet to be, for heresy though it seem to say so in this journal, it is our social heredity that preserves the best the race has wrought out of space and time, and the unmodifiable germplasm is, after all, more a matter of concern to the microscopist and biochemist than it is to our harvest of boys and girls. The hope I see for putting over Eugenics to the masses who need it most lies in the new interpretation of the world's poetry and romance, the making of life now and here romantic and interesting and splendidly worth while, so that we shall strenuously desire to perpetuate it and enjoy the holy fruits of its perpetuation, and this will be done only when we do as has been suggested, turn the current of humanity's genius into social channels and evolve as magnificent engines for social rightcousness as we have for the discovery and control of weakness, disease and death. That this can and will be done we may already read in the signs of the times, not the least of these our Scouts and Camp Fire. 